\title{
Punishing Survivors and Criminalizing Survivorship: A Feminist Intersectional Approach to Migrant Justice in the Crimmigration System
}

\author{
SALINA ABJI \\ Canada
}

\begin{abstract}
Scholars have identified crimmigration - or the criminalization of "irregular" migration in law - as a key issue affecting migrant access to justice in contemporary immigrant-receiving societies. Yet the gendered and racialized implications of crimmigration for diverse migrant populations remains underdeveloped in this literature. This study advances a feminist intersectional approach to crimmigration and migrant justice in Canada. I add to recent research showing how punitive immigration controls disproportionately affect racialized men from the global south, constituting what Golash-Boza and Hondagneu-Sotelo have called a "gendered racial removal program" (2013). In my study, I shift analytical attention to consider the effects of the contemporary crimmigration system on migrant women survivors of gender-based violence. While such cases constitute a small subgroup within a larger population of migrants in detention, nevertheless scholarly attention to this group can expose the multiple axes along which state power is enacted - an analytical strategy that foundational scholars like Crenshaw (1991) used to theorize "structural intersectionality" in the US. In focusing on crimmigration in the Canadian context, I draw attention to the growing nexus between migration, security, and gender-based violence that has emerged alongside other processes of crimmigration. I then provide a case analysis of the 2013 death while in custody of Lucía Dominga Vega Jiménez, an "undocumented" migrant woman from Mexico. My analysis illustrates how migrant women's strategies to survive gender-based violence are re-cast as grounds for their detention and removal, constituting what I argue is a criminalization of survivorship. The research overall demonstrates the centrality of gendered and racialized structural violence in crimmigration processes by challenging more universalist approaches to migrant justice.
\end{abstract}

KEYWORDS crimmigration; migrant justice; intersectionality; gender; race; illegality; gender-based violence; immigration detention; Canada 
On December 1, 2013, Lucía Dominga Vega Jiménez - an undocumented migrant woman of colour from Mexico - was apprehended by Canadian border authorities in Vancouver after being pulled aside by transit officers for a fare-enforcement infraction. Lucía was subsequently held in immigration detention for 19 days, the majority of which she spent in prison - a controversial practice given that immigration detention is supposed to be administrative in nature and not punitive (Global Detention Project, 2012; Amnesty International, 2015; United Nations Committee on Human Rights, 2015). On the day before Lucía was scheduled to be deported, she attempted suicide in an airport detention facility monitored by a private-security firm with no training in trauma-informed crisis response (Burgmann, 2014; Dawson, 2016). Lucía later died in hospital, although news of her death was not made public until one month after she passed, when a journalist caught wind of the case and began asking questions (Dyck, 2015).

Migration scholars have approached cases like Lucía's as mounting evidence of "crimmigration" (Stumpf, 2006), defined as state laws, policies, and practices that work to criminalize a range of irregular and temporary forms of migration. The US crimmigration system is characterized by increasing convergences between criminal law and immigration policy, where unauthorized forms of migration are more likely to be punished as criminal infractions rather than administrative violations as has historically been the case (Armenta, 2017; Hernández, 2017; Menjívar, Cervantes \& Alvord, 2018). In the Canadian case, remaining in a country without authorization is still on the books as a civil infraction, yet the tactics used to enforce immigration controls are increasingly punitive - constituting what Weber (2002) terms procedural and symbolic criminalization. The tactics of crimmigration in Canada range from political discourse and immigration policies that frame (often racialized and poor) refugee claimants and asylumseekers as "bogus" or fraudulent, to the police-style tactics of immigration raids and the housing of detainees in jails without time limits on how long an individual can be held (Arbel \& Brenner, 2013; Bosworth \& Turnbull, 2014; Goldring \& Landolt, 2013; Walia, 2013; Razack, 2017; Silverman, 2014). ${ }^{1,2}$

While scholarship on crimmigration has provided important insights into the forms of injustice that migrants like Lucía increasingly encounter at the border and beyond, the gendered and racialized implications of crimmigration remain largely underdeveloped in this literature (Garner, 2015; Golash-Boza $\&$ Hondagneu-Sotelo, 2013). Indeed, a number of feminist and critical race

\footnotetext{
${ }^{1}$ Although estimates suggest between 200,000-500,000 non-status migrants living in major cities across Canada, there is no publicly available reliable data on this population (Goldring, Berinstein \& Bernhard, 2009). The fact that these numbers have been cited for over a decade remains a major issue.

${ }^{2}$ Migrants living without legal status in Canada may have (often ineffectual) status elsewhere such as their countries of origin, but a small percentage have no status anywhere and are stateless.
} 
scholars have intervened in recent years to better unpack how race, gender, and other axes of difference are mobilized in the enactment of punitive immigration controls (Armenta, 2017; Cervantes, Menjívar \& Staples, 2017; Menjívar et al., 2018; Moffette, 2018). Taken together, these scholars have begun to show the disproportional impacts of mass deportation and detention on racialized men from the global south, who are more likely to be framed as criminals and threats to the social order as a justification for the scaling back of rights (Golash-Boza, 2016; Pratt, 2005). I add to this research by using a feminist intersectional approach to consider the gendered and racialized implications of crimmigration for migrants like Lucía. In doing so, I shift analytical attention to Lucía's complex positionality - not only as a migrant woman of colour living without authorization in Canada, but also as a survivor of gender-based domestic violence, whose claim for refugee status was denied by the Canadian state. ${ }^{3}$ In doing so, I draw from the foundational work of feminist intersectional scholars like Crenshaw (1991) who positioned the issue of gender-based violence against women of colour as central to theorizing structural intersectionality. Crenshaw defines structural intersectionality as the co-constitution of gendered, racialized, and classed structures of state power in law (see also Bhuyan, Osborne, Zahraei \& Tarshis, 2014; Maynard, 2017; Walia, 2013). I apply this approach to extend crimmigration scholarship, providing a reading of Lucía's case that is informed by my own fieldwork and interviews with service providers working within the anti-violence against women sector in Toronto, Canada (Abji, 2016, 2018; Abji, Korteweg \& Williams, 2019; Bergen \& Abji, 2020). I argue that what gets criminalized in such cases is not only irregular migration, but also the strategies of survivorship that racialized and migrant women have developed to address the multiple forms of violence in their lives. The research thus draws important attention to what I argue is a growing nexus between migration, security, and gender-based violence that is largely overlooked by literature on crimmigration, and that extends more recent feminist and critical race critiques of the crimmigration thesis.

The article begins by defining crimmigration and its impact on irregular migrants in the Canadian detention system. I then return to early work by feminist intersectional scholars to develop my analytical framework, which centres the lived experiences of racialized migrant women survivors of gender-based violence in detention. In applying this analytical framework to my reading of Lucía's tragic death in detention, I trace the gendered and

\footnotetext{
${ }^{3}$ While it is beyond the scope of this paper, the experiences of (racialized and poor) trans-people in immigration detention is another under-studied sub-group that is likewise important for examining the structural violence of crimmigration (Collier \& Daniel, 2019; Lee, 2019). In this paper, I use the category women to refer to women-identified individuals, recognizing the fluidity of gender identity.
} 
racialized injustices that survivors experience in a system that not only criminalizes their migration pathways, but also criminalizes the strategies of survivorship developed by migrant women and their advocates to navigate the multiple sources of violence in their lives.

\section{Crimmigration and Migrant Justice in Canada}

Since the early 2000s, scholars have approached state practices of mass deportation and detention as evidence of a growing crimmigration system (Bourbeau, 2018; Hernández, 2017; Stumpf, 2006). In the US context, which has predominated within crimmigration scholarship, the decision to re-enter a country from which one has been deported is punishable as a criminal offence under regulations introduced in 1996 (Stumpf, 2006). ${ }^{4}$ As crimmigration scholars have argued, the move to treat irregular migration as a crime rather than a civil infraction has played a major factor in the direct criminalization of migrant populations (Armenta, 2017; Hernández, 2017). Importantly, this convergence between criminal and civil law is always partial: that is, it often does not come with the same (albeit limited) protections such as the right to appeal, the right to appointed counsel, protection against self-incrimination, and other constitutional rights (Stumpf, 2006, pp. 392-395). As such, the forms of migrant injustice experienced by illegalized migrants in a crimmigration system are often two-fold: consisting both of forms of criminalization for infractions that used to be considered civil infractions, as well as an absence of basic civil liberties afforded at least in theory to citizens who commit crimes. Crimmigration in the Canadian context has received less attention compared to the US, in part because irregular migration still remains on the books as a civil infraction. Likewise, the population of non-status migrants in Canada is a smaller percentage of the population compared to the US, and rates of deportation and detention are also much lower in the Canadian case. ${ }^{5}$ Yet, as I and others have argued, processes of crimmigration and the related securitization of migration have nevertheless shaped migrant precarity in Canada, and certainly shaped the tragic circumstances surrounding Lucía's death (Abji, 2016; Bergen \& Abji, 2020; Bosworth \& Turnbull, 2014; Goldring \& Landolt, 2013; Molnar \& Silverman, 2018).

There are three interrelated factors that characterize crimmigration in the Canadian immigration system: (1) criminalizing and restrictive immigration

\footnotetext{
${ }^{4}$ Under the 1996 Illegal Immigration Reform and Immigrant Responsibility Act (IIRIRA).

${ }^{5}$ Numbers of deportations in Canada have declined steadily in recent years under the Liberal government, peaking in 2012 at 18,921 removals under the previous government (CBSA, n.d.). Detentions in Canada peaked in 2013 with 14,362 detentions that year. Rates have since levelled off to between 6,000-8,000 detainees per year at the time of writing (GDP, 2012, 2018). For a more detailed discussion on the factors shaping migrant precarity in Canada compared to the US see Goldring et al. (2009) and Goldring \& Landolt (2013).
} 
regulations, (2) police-style border enforcement tactics, and (3) punitive conditions of detention without independent oversight. For example, a series of changes to refugee determination introduced between 2008 and 2014 introduced symbolic and procedural criminalization in the treatment of refugee claimants and asylum-seekers (Atak, Hudson \& Nakache, 2018; Béchard \& Elgersma, 2012; Bhuyan et al., 2014; Weber, 2002). The rightwing Conservative government in power at the time mobilized criminalizing notions of fraudulent or "bogus" refugees to justify restrictions on access to permanent residency, often combined with neoliberal rationalizations of efforts to cut down wait times and the backlog of so-called legitimate claims (Silverman, 2014). ${ }^{6}$ For example, refugee claimants from Mexico were reclassified under changes introduced in 2012 under Bill C-31 as claimants from "safe" countries or "Designated Countries of Origin" (DCO). By classifying Mexico as a "safe" country and hence unlikely to produce refugees, legislators justified restrictions on the timelines for making claims (from 60 days to $30-45$ days) - a seemingly bureaucratic change that in reality imposed procedural unfairness based on country of origin, given that claimants had less time to secure a lawyer and to prepare necessary testimony for making their claims (Atak et al., 2018). Claimants under DCO also had no right of appeal, although they could ask for a federal court review but would remain deportable during this time (Béchard \& Elgersma, 2012). The federal government was widely criticized for including countries like Mexico and Hungary on the list of "safe" countries given well-documented human rights abuses and targeting of minority groups such as state impunity in the deaths of women (or femicide/feminicide) in Mexico and the political persecution of Roma refugees in Hungary (García-Del Moral, 2016; JRIC, 2012). ${ }^{7}$

These criminalizing restrictions targeting immigration "fraud" and "bogus" refugees were coupled with the expansion of police-style border enforcement tactics in the post-9/11 period. In 2003, the Canadian government created the Canada Border Services Agency (CBSA) and soon after launched a multipleborder strategy that included inland enforcement by both uniformed and plain-clothed officers seeking out undocumented migrants in workplaces, hospitals, transit, schools, child welfare and women's shelters (Abji, 2016; Arbel \& Brenner, 2013; Bhuyan et al., 2014). Crimmigration scholars have pointed to the mirroring of police tactics by immigration authorities as a key component of the criminalization of irregular migration, and often buttressed

\footnotetext{
${ }^{6}$ Importantly, the regulatory changes introduced by the federal Conservative party were the culmination of decades of both Liberal and Conservative restructuring of the refugee and immigration system introduced through neo-liberalization of social services such as settlement and migration in the 1990s. These "reforms" were intensified with the rise of more right-wing Conservative policies on immigration and security in the post-9/11 period (Abji, Korteweg \& Williams, 2019; Bhuyan et al., 2014).

${ }^{7}$ In May 2019 the Liberal party in power removed all countries from the DCO list.
} 
by cooperation with local police (Stumpf, 2006). Moreover, critical race scholars have extended this analysis by showing how punitive immigration enforcement often mobilizes dominant notions of racialized communities as more dangerous or as sites of criminal or terror-related activities requiring increased profiling and surveillance (Armenta, 2017; Moffette, 2018; Romero, 2008).

A third interrelated factor of crimmigration in Canada is punitive conditions of immigration detention. Scholars have documented the wide degree of discretion that individual officers have for detaining migrants both prior to deportation, as well as for those attempting entry such as certain classes of asylum-seekers and unauthorized border crossers under legislation introduced in 2012 (Moffette, 2018; Silverman, 2014). ${ }^{8}$ Critical race scholars have extended these findings to show how dominant ideas of racialized men as security threats or criminals are mobilized in these everyday moments of discretionary power by border officers. This criminalizing discourse obscures the ways in which the detention of these groups facilitates global capitalism by removing those dispossessed by economic restructuring (Golash-Boza, 2016). Indeed, by the CBSA's own admission, roughly one-third of detainees held in 2009-2010 were failed asylum-seekers considered "low-risk" by officials at the time of their detention (EIDN, 2014; GDP, 2012). What this in effect means is that people are being detained in part because their stated fear of returning (where they may face death, harm, or human rights abuses) could easily lead to an officer considering them a flight risk and then detaining them.

The discretionary power of officers to detain is exacerbated in Canada by the lack of independent oversight of the CBSA coupled with the controversial practice of holding detainees in jails rather than administrative holding centres. ${ }^{9}$ This gives rise to procedural forms of criminalization, where a lack of clear jurisdiction between provincial jails and the federal border agency leads to punitive treatment. Indeed, the Global Detention Project has reported cases where prison guards were not even aware of which prisoners were immigration detainees being held on administrative grounds and which were serving sentences for crimes (GDP, 2018). It is thus unsurprising that the mental health needs of migrant detainees - who may have experienced trauma from war or displacement and who often experience psychological and physical symptoms during the removal process - are often overlooked

\footnotetext{
${ }^{8}$ The federal Conservative government passed anti-smuggling legislation (Bill C-31) in 2012, which included provisions for mandatory detention for "irregular arrivals" (see Atak et al., 2018).

${ }^{9}$ Canada routinely detains non-citizens in jails rather than administrative holding centres that are specifically designed for immigration detainees (GDP, 2018; Pratt, 2005). Roughly 40-60\% of detainees are held in correctional facilities on any given day, where they mix with the prison population and have limited access to legal, medical, and social supports (Gros \& Van Groll, 2015).
} 
and rarely understood in a prison system that is already limited in the availability of health supports (Gros \& Van Groll, 2015).

These punitive conditions are further exacerbated in the Canadian case, where migrants can be held indefinitely as there are no current time limits on detention as in other immigrant-receiving countries (GDP, 2018; Track \& Paterson, 2017). Importantly, the indefinite nature of detention has been compared to psychological torture and is widely regarded by the $\mathrm{UN}$ and international human rights organizations as an arbitrary and unjust deprivation of human liberty (Gros \& Van Groll, 2015; Track \& Paterson, 2017). Canadian human rights organizations and activist groups have brought to the attention of the UN the multiple human rights violations that migrant detainees experience: while the UN has reprimanded Canada for its use of jails and indefinite detention, at the time of writing there has been no movement on the part of the government to establish an independent armslength body for addressing and investigating non-citizens' complaints against the CBSA (UNHCR, 2012; United Nations Committee on Human Rights, 2015). ${ }^{10}$

The crimmigration thesis thus offers a compelling if harrowing analysis of immigration detention in Canada. However, a growing number of feminist and critical race scholars have argued that the crimmigration thesis is not enough - more attention to the intersectional dynamics of crimmigration with other systems of oppression such as gender, race, and class is needed to fully understand the forms of migrant injustice that diverse populations experience (Bosworth, Fili \& Pickering, 2016; Golash-Boza, 2016; Golash-Boza \& Hondagneu-Sotelo, 2013; Maynard, 2017; Nobe-Ghelani, 2016; Razack, 2017; Walia, 2013). In what follows, I outline a feminist intersectional approach for analyzing such cases and then apply this approach to a deeper reading of Lucía's story as evidence of the criminalizing of migrant women's strategies of survivorship at the nexus of migration, security and genderbased violence.

\section{Advancing Feminist Intersectional Approaches: Centering the Survivorship of Migrant Women of Colour}

A feminist intersectional approach to crimmigration extends beyond a singular focus on the convergence between criminalization and immigration

\footnotetext{
${ }^{10}$ At the time of writing, the Liberal government has ear-marked funds for an arms-length monitoring unit for CBSA in its 2019 budget, following decades of activist organizing and at least 16 reported deaths in immigration detention since 2000 (Molnar \& Silverman, 2018; Tunney, 2019). However, the implementation of this unit has yet to materialize. Activists remain cautiously optimistic.
} 
in law, policy and practice. Rather, such an approach examines the constitutive role that race, gender, class, and other salient axes of difference play in shaping the processes and effects of crimmigration across diverse migrant populations. In their work on mass deportation and detention in the US, Golash-Boza \& Hondagneu-Sotelo (2013) use such an approach to analyze the disproportional impacts of punitive immigration controls on racialized men from the global south. They explain how crimmigration processes function as a "gendered racial removal program" where dominant notions of racialized masculinity as threatening (whether by virtue of criminality or security threats) are used to justify the expulsion of a group whose labour power is expendable after decades of neoliberal restructuring and the crisis of global capitalism (Golash-Boza \& Hondagneu-Sotelo, 2013). Dominant notions of racialized masculinity as threats are powerful in part because they draw from tropes that are deeply-embedded in histories of settler-colonialism and racial capitalism that continue to shape and inform national identity (Glenn, 2015; Maynard, 2017; Stasiulis \& Jhappan, 1995).

More recently, Cervantes et al. (2017) analyzed the racialized and gendered logics used to justify the detention of Latin-American female detainees in the US, as well as a growing for-profit industry providing alternatives to detention. Here they show differences in how racialized femininity is mobilized by state authorities, in this case drawing on dominant notions of Latina women as threats to the social order in terms of their reproductive power, their sexuality, or as "burdens" on the welfare state. On the surface, these stereotypes seemed to produce less punitive treatment compared to the treatment of racialized men, such as alternatives to detention that position the state as a paternalistic protector of so-called bad mothers whose vulnerabilities must be weighed against punishment. However, as Cervantes et al. (2013) show, this "soft punishment" translates into equally punitive treatment in practice within a carceral system. Indeed, emerging scholarship on migrant women in detention is buttressed by a burgeoning grey literature documenting the forms of discrimination that migrant women experience in detention (Brané \& Wang, 2013; Molnar \& Silverman, 2018; NIJC, 2014; Rabin, 2009). ${ }^{11}$ Detained women are more likely to be asylum-seekers compared to men; they are more likely to be single-parents compared to men, with less overall social support in mitigating the effects of incarceration for themselves and their families; and women are more likely than men to report experiencing domestic violence or sexual assault prior to detention (Brané \& Wang, 2013; NIJC, 2014; Rabin, 2009).

\footnotetext{
11 There is also a growing grey literature documenting the detention of children, whether unaccompanied or as part of family units (Gros, 2016). In the Canadian case, children accompanying single mothers have been counted by CBSA as "visitors" rather than detainees, and until recently have not been included by CBSA in official statistics.
} 
In the Canadian case, there is a significant lack of publicly available data on the number of men, women, and trans people in detention, let alone on the prevalence of sexual violence. ${ }^{12,13} \mathrm{I}$ thus build upon this growing body of scholarship to begin tracing the racialized and gendered dimensions of migrant justice in the crimmigration system. In doing so, I return to early feminist work on intersectionality, which centred the issue of gender-based violence as central to understanding Black women's experiences (Combahee River Collective, 1983; Crenshaw, 1991; Lorde, 1984; see also Glenn, 2015; Maynard, 2017; Walia, 2013; Carasthathis, Kouri-Towe, Mahrouse \& Whitley, 2018).

For early-intersectional theorists like Crenshaw and others, the issue of violence against women of colour was central to any structural analysis. This was in part because they understood the ways in which state power and the political movements that resist state power could produce multiple forms of violence and erasure in racialized women's lives over and above the interpersonal forms of violence typically studied. In her widely-cited article, Crenshaw (1991) theorizes structural intersectionality as the co-constitution of gendered and racialized structures of state power in law. She argues that by centering the experiences of women of colour, scholars can tease out the ways in which different systems interact to produce particular forms of precarity that are obscured when focusing solely on singular analysis, such as race-based analyses that assume a male subject, or gender-based analyses that assume a white subject. Writing at a time when the US crimmigration system was in its infancy, Crenshaw's structural-intersectional analysis of genderbased violence was prescient in calling attention to the role of deportation and immigration policy as one of several key factors shaping access to justice for Black women - an aspect of her early work that has been largely overlooked (1991, p. 1245). Crenshaw offers two critiques of restrictive immigration controls in theorizing structural intersectionality. First, she challenges the lack of a race and gender-based analysis in legislation targeting immigration "fraud' which neglects to consider the effects of such policies in increasing racialized women's risks of gender-based violence (1991, p. 1247). Second, she critiques legal changes that take gender into account but assume a white, middle-class female subject. In such cases, the specificities of minority women's experiences are excluded, thus producing barriers for individual women to access supports. Moreover, Crenshaw points to how women of colour and their families and communities are perversely criminalized

\footnotetext{
${ }^{12}$ A recent journalist investigation found five reported allegations of sexual assault within the CBSA between 2016-2018 but no details were available on the outcome or actions taken (Swain, Wesley \& Davis, 2019).

${ }^{13}$ In terms of demographics, earlier accounts from scholars suggest that roughly $70-75 \%$ of detainees are male, and that racialized men from the global South are the dominant group in detention in Canada (Pratt, 2005).
} 
through such efforts to protect white women (Crenshaw, 1991, pp. 12481249).

Crenshaw's early work on the structural violence of immigration controls for survivors of gender-based violence has been followed by a burgeoning feminist field addressing this issue (Abji, 2018; Abji et al., 2019; Bhuyan et al., 2014; Glenn, 2015; Maynard, 2017; Stasiulis \& Bakan, 2005; Walia, 2013). Taken together, feminist critiques of immigration controls in Canada illustrate what I have termed a growing nexus between migration, security and gender-based violence. This nexus includes formalized practices of border officials entering women's shelters or standing around the perimeter as part of the broader crackdown on migrant populations living without status (Abji, 2016; Villegas, 2015). It also includes legislation targeting genderbased violence introduced by the right-wing Conservative government, such as the "Zero Tolerance for Barbaric Cultural Practices Act" introduced in 2014, which combined new restrictions on immigration with changes to criminal and family law, thus mobilizing the issue of gender-based violence to advance a carceral crimmigration agenda (Abji et al., 2019; Singh, 2016). By bringing attention to this nexus in my re-reading of Lucía's experiences of detention and death, I thus extend crimmigration scholarship as well as recent critiques by feminist and critical race scholars. In what follows, I outline my methodology before turning to Lucía's story.

\section{Methodology}

While there have been at least 16 reported deaths in immigration detention in Canada since 2000, Lucía's story offers an important - if harrowing opportunity to analyze the experiences of survivors of gender-based violence in detention (GDP, 2018; Molnar \& Silverman, 2017). Because her case received national media attention along with a widely publicized coroner's inquest and social movement advocacy campaigns, there are more details of her story publicly available for analysis compared to other deaths in detention. This is important for research on immigrant detainees, since researchers must navigate a complex process of protecting migrant vulnerability and privacy while trying to make visible that which state institutions actively try to render invisible (Goldring \& Landolt 2013). My analysis of Lucía's story is thus illustrative rather than representative, offering only those details that are publicly available in order to develop an analytical model for theorizing migrant justice more broadly.

My methods were three-fold. First, I conducted discourse analysis of thirtyfour artifacts directly relevant to Lucía's case, including newspaper articles, CBSA memos, the coroner's inquest report, campaign press releases, and policy reports. In my analysis I coded examples of symbolic, procedural and direct criminalization across three intersecting axes of oppression: immigration status, racialized-gender, and gendered-racialization (Glenn, 
2015). I then triangulated this analysis with findings from my broader research project examining the impacts of immigration policies on survivors of gender-based violence. This included data from my ethnographic fieldwork among migrant rights activists in Toronto (2011-2015) and interviews with 30 service providers working with migrant women survivors of gender-based violence. When the story of Lucía's tragic death in detention made national headlines in January 2014, I was in the midst of conducting fieldwork and interviews, and thus had the opportunity to discuss the impacts of detention on survivors with a sub-sample of interviewees. While the interviewees were based in Toronto (not Vancouver where Lucía was detained), they nevertheless were key informants with 15 to 25 years of experience working with refugee and migrant women across a range of organizations such as women's shelters, settlement agencies, and legal and medical clinics. Through active participation in the field, I also co-organized a community forum in Toronto on immigration detention, which included a live re-enactment of a detention hearing of a racialized migrant woman detainee, followed by lively discussion among activists and service providers who work with migrant women survivors. My analysis of Lucía's experiences in detention is thus grounded in extensive fieldwork among migrant rights groups, to which I bring added insights from feminist intersectional scholarship on migrant justice and gender-based violence.

In what follows, I first offer an account of Lucía's story, focusing on police-style border enforcement practices and punitive conditions of detention that shaped her experience. I then apply an intersectional analysis to trace mutually-constituting factors of gender, race, and immigration status that together produce migrant (in)justice for survivors of gender-based violence. Through this unpacking, I argue that migrant women's strategies of survivorship are criminalized - symbolically and procedurally - leading to a form of migrant injustice not adequately captured in existing scholarship on crimmigration.

\section{Honouring Lucia's Story: Crimmigration and Migrant (In)justice in Canada}

Lucía Dominga Vega Jiménez was a Mexican national whose application to remain in Canada as a refugee was denied in 2010. While details of her refugee claim are private, the inquest into her death revealed that she feared violence from an abusive ex-boyfriend as well as fear of "torture and death" were she to return to Mexico (Ministry of Justice, 2014). When her refugee claim was rejected in 2010, Lucía applied to have her case reviewed by the federal court, but her application was dismissed (Woo, 2014). It is believed that the CBSA initially deported Lucía to Mexico, and that she subsequently re-entered Canada without authorization where she lived without status and 
worked for cash as a cleaner at a Vancouver hotel (Burgmann, 2014; Woo, 2014). Under Canadian law, Lucía's decision to re-enter Canada without authorization was a civil infraction (i.e., not a criminal infraction). Yet, as I go on to show, the procedures used to detain her, along with the conditions of her detention, were highly punitive in practice and constituted evidence of crimmigration for non-citizens in Canada.

Lucía was detained on December 1, 2013. At the time, she was travelling on the Vancouver SkyTrain when transit officers pulled her aside after she could not produce proof of payment. Instead of issuing her a ticket, transit officials called the CBSA who checked Lucía's name against their database and dispatched an officer to the scene. As legal scholars have pointed out, Lucía was not informed of the right, nor given the opportunity, to speak to a lawyer before the CBSA officer questioned her at the SkyTrain office (Gros \& Van Groll, 2015). According to a lawyer from the BC Civil Liberties Association, the CBSA officer "purported to be her friend and introduced herself as a 'liaison person"” (Gros \& Van Groll, 2015). However, she asked Lucía questions "that, when answered, resulted in self-incrimination, and the resulting information was eventually used against her in a detention review hearing" (Gros \& Van Groll, 2015).

When news reports of Lucía's death surfaced, activists in Vancouver launched a "Transportation Not Deportation" campaign to protest what they saw as clear and on-going racial profiling of Latino, Black, and Indigenous communities by Vancouver transit police (TND, 2015). ${ }^{14}$ It was soon revealed that a Memorandum of Understanding (MOU) had been in place between Greater Vancouver Transportation Authority and the CBSA at the time that Lucía was questioned by transit officers who then notified the CBSA, triggering her detention by authorities (Ball, 2014; TND, 2015). But Lucía could just as easily have been apprehended by border officers at her workplace or in going about her daily life - a form of precarity that scholars have shown has negative psychological effects on migrant well-being as well as intensifying the risks of exploitation from abusers threatening to report migrants to authorities such as employers, landlords, intimate partners and family or community members (Bhuyan et al., 2014; Goldring \& Landolt, 2013).

Lucía was subsequently held in immigration detention for 19 days, the majority of which she spent at Alouette Correctional Centre for Women (ACCW), a provincial jail. As noted at the inquest, Lucía was issued prison clothes and was held in the high-risk portion of the jail, despite being detained for administrative reasons (Ministry of Justice, 2014).

\footnotetext{
14 According to an internal CBSA memo obtained by the TND campaign via freedom of information request, in 2013 transit police made 328 referrals to CBSA, of which 62 resulted in investigations for removal (TND, 2015).
} 
The inquest showed how her repeated requests for medical appointments to deal with physical and mental health symptoms were ignored - in one case due to a bureaucratic error where the prison database mistakenly showed that she had already been transferred to another facility leading to a cancelled medical appointment (Ministry of Justice, 2014). Records of her final request for medical care showed that Lucía self-identified as needing "crisis" level support, yet without any independent oversight her family had little legal recourse to address potential violations of Lucía's right to basic health supports - a complaint that had a better chance of being addressed if Lucía had been incarcerated for a criminal offence rather than a civil violation. ${ }^{15}$

When Lucía was handcuffed and transferred to the Vancouver airport detention facility or "Immigration Holding Centre" (IHC) the day before her scheduled deportation, she was held in a facility described by advocates as a "dungeon" with no windows and where even the lawyers of detainees report being unable to access their clients housed there (Shantz, 2014; Ministry of Justice, 2014; Walia \& Hassan, 2014). Although the Vancouver facility is operated by the CBSA, the government contracts out elements of the operation to private companies, including the private security firm that was responsible for Lucía's safety and security at the time of her detention (GDP, 2018). According to the inquest, the CBSA had failed to adequately monitor and address on-going problematic practices on the part of the private security company: the officers on duty during Lucía's detention had falsified the logs indicating that they had done rounds of the facility whereas they had instead been playing video games in the office (Ministry of Justice, 2014).

On the day before Lucía was scheduled to be deported, she attempted suicide in an airport detention facility monitored by a private-security firm with no training in trauma-informed crisis response (Burgmann, 2014; Dawson, 2016). At the time of Lucía's attempted suicide in the facility, there was also no female officer on duty, and officers had received no training in providing trauma-informed crisis response (outside of basic first aid and training in how to handcuff and detain prisoners). The facility itself was also not equipped with standard harm-prevention protocols used in jails, which might have prevented Lucía from being able to attempt suicide by hanging herself in the shared shower facilities. It was only when other detainees alerted the security officers by repeatedly banging on the door of their office that an officer was able to break into the locked bathroom and attempt to resuscitate Lucía. Lucía never regained consciousness and later died in hospital on December 24, 2013. She was 42 years old. The news of Lucía's

\footnotetext{
${ }^{15}$ Coroners inquests by definition cannot find "fault" but can only make recommendations (Molnar \& Silverman, 2018; Paterson, 2014; Shantz, 2014). The jury at Lucía's inquest made 23 recommendations including that an independent Ombudsman be appointed to mediate any complaints put forward (Ministry of Justice, 2014).
} 
death was not made public until one month after she passed, when a journalist caught wind of the case and began asking questions.

\section{Punishing Survivorship, Criminalizing Survivors: A Feminist Intersectional Analysis of Lucía's Story}

The regulations targeting immigration "fraud" and "bogus" refugees that shaped Lucía's migration pathway were problematic in lacking a gender and race-based analysis. By declaring Mexico a "safe" country, the legislation failed to recognize pressing issues of feminicide and state impunity in addressing the deaths of Mexican women, as well as the role that Canadian foreign policy may have played in intensifying conditions of poverty and instability that form part of the conditions of violence in Mexican women's lives (Aberman, 2014). Shortened timelines for making refugee claims also lacked a trauma-informed approach to refugee determination: such an approach would take seriously the uneven process that survivors of genderbased violence often require to make sense of their experiences of violence and the effects of trauma in being able to recount details, as well as the significant barriers that survivors may encounter in collecting the necessary evidence to support claims (Bhuyan et al., 2014). While changes to the refugee determination process were thus problematic for all refugee claimants hailing from so-called safe countries, gendered and racialized notions of safety and legitimacy shaped the forms of political and procedural injustice experienced by migrant women seeking to survive gender-based violence in situations where they felt unsafe enough to uproot their lives.

Most of the service providers I interviewed also described how regulatory changes not only punished women's attempts to migrate as a survival strategy, but also criminalized the strategies that advocates themselves had developed over decades of anti-violence work. For example, in the early 1990s, feminist activists were successful in pressuring the Canadian government to develop the first gender-based policy recognizing genderbased violence and other forms of gendered persecution as legitimate grounds for filing a refugee claim in Canada (Abji, 2016). This policy helped establish Canada's reputation on the world stage as a leader in addressing the gendered dimensions of refugee determination. However, in the decades that followed, contradictions emerged between policy and practice when claimants filing gender-based refugee claims encountered re-victimization and discrimination in the process - including, for example, dominant myths about sexual violence that positioned racialized women in particular as lying to take advantage of Canada's humanitarian policies (Bhuyan et al., 2014; see also McKinnon, 2016).

Many of the service providers I spoke to described how they developed strategies to help women in crisis navigate a problematic system: one such strategy, for example, involved applying for Humanitarian and 
Compassionate $(\mathrm{H} \& \mathrm{C})$ grounds to remain in the country at the same time that one filed a refugee claim. This double-application allowed migrant women survivors to better negotiate re-victimization and improve their chances of obtaining permanent residency as a key strategy in violence prevention. If a woman's claim for refugee status based on gender-based violence was rejected, she could remain in the country while her H\&C claim was being processed. The lengthy timelines for refugee applications to be processed also allowed applicants to gather the necessary evidence to build their H\&C case, such as evidence of strong ties to the community - a factor that many survivors struggled with given the effects of isolation, poverty, and trauma typically associated with domestic violence. However, in 2012, the federal government introduced a one year bar on applying for $\mathrm{H} \& \mathrm{C}$ for failed refugee claimants, during which time migrant women like Lucía would have been deportable (Mattoo, Mann \& Romano, 2017). The service providers I interviewed highlighted this change in particular as evidence that the strategies of survivorship that they had themselves developed as advocates to help survivors navigate a racist and sexist system, were being systematically criminalized through restrictive regulations (Abji, 2018).

The lack of an intersectional and trauma-informed analysis in regulations targeting refugee protection was coupled with expanded border enforcement practices at this time. Initially, the CBSA's practice of police-style border enforcement tactics also lacked an intersectional analysis. Indeed, there is a large body of feminist scholarship showing the effects of women's fears of deportation in cases of domestic or interpersonal violence: abusers often use threats of deportation as a tool of power and control, and women's fears of being deported (or having their family members deported) may prevent them from reporting or leaving abusive situations (Bhuyan et al., 2014; Carasthathis et al., 2018; Crenshaw, 1991; Razack, 2002; Stasiulis \& Bakan, 2005; Walia, 2013). This is true also for other forms of gender-based violence, such as sexual harassment, sexual assault and rape at the hands of employers, landlords, faith leaders, family or community members, or others in positions of power. The service providers whom I interviewed pointed out, however, that the increased presence of border officers (uniformed and plainclothed) that they witnessed as CBSA expanded its practices, made it much more difficult to mitigate against migrant women's fears of deportation particularly for racialized women whose communities were already overpoliced. Several described a case in 2006 when a racialized non-status woman was handed over to the CBSA by Toronto Police after reporting domestic violence to authorities (Landolt \& Goldring, 2013). Activists immediately responded to the case and were successful in pressuring the Toronto Police to adopt a "Don't Ask" policy, where police officers were not to ask about immigration status unless they had a bona fide reason to do so (Abji, 2018). However, activists were unsuccessful in their attempts to combine this with a "Don't Tell" policy, meaning that there is no firewall that 
prevents Toronto police from reporting cases to the CBSA (Abji, 2018). At the time of Lucía's detention, Vancouver police had no DADT (Don't Ask, Don't Tell) policy in place, thus affecting the likelihood of non-status witnesses or victims of crime coming forward to report. ${ }^{16}$

When more reports began to surface of CBSA officers entering or standing around the premises of women's shelters and agencies offering anti-violence against women programs, activist groups across the country launched a national campaign in 2008 against the practice, called the "Shelter Sanctuary Status" campaign (Abji, 2016; Villegas, 2015). It was largely in response to pressure from advocates that the CBSA decided to formalize its problematic practices: in 2011, the agency issued a policy directive outlining its justification for entering women's shelters, which included a series of protocols for how to do so with "sensitivity" (Abji, 2016). As I have argued elsewhere, the directive re-framed women's human rights to protection from gender-based violence as a "lower order" concern - equivalent to that of a special interest group - that did not detract from the state's sovereign authority to enforce borders across any territory in its jurisdiction, including women's shelters (Abji, 2016, 2018). What this assertion in fact produced, I argue, is a criminalized framing of women's efforts to survive - through, for instance, seeking shelter or protection from gender-based violence - where the act of living without authorization is decontextualized and rendered a threat to the safety of the Canadian population that can only be addressed through removal (Abji, 2016). Thus, the CBSA's justification of border enforcement in women's shelters was implemented despite protests from activist groups, including major state-funded women's organizations. In this way, the CBSA prioritized discourses of national security and risk to safety for the Canadian population over decades of feminist research and activism on the role of deportation as a barrier in the global fight against gender-based violence.

This re-casting of migrant women's efforts to survive as acts requiring expulsion can likewise be seen in the framing of Lucía's expressed fears of returning to Mexico as constituting a flight risk requiring her detention. Indeed, many of the service providers I interviewed were critical about the discretion of individual CBSA officers to detain as a type of "entrapment" for survivors of gender-based violence, where survivors' fears of violence and death at the hands of abusive partners were perversely understood as justifications for deprivation of liberty - a particularly egregious practice given international guidelines on the use of administrative detention as "a last resort" (Amnesty International, 2015).

\footnotetext{
${ }^{16}$ At the time of writing, Vancouver police have adopted a similar policy as Toronto where they will not ask about immigration status "unless there is a legitimate reason" to do so, again leaving the practice itself open to the discretion of individual officers (Canadian Press, 2018).
} 
In Lucía's case, a Pre-Removal Risk Assessment (PRRA) could have acted as a safeguard against deportation to a situation of high risk (i.e., risk of persecution, torture, risk to life, cruel or unusual punishment). The service providers I spoke to who worked with failed refugee claimants like Lucía, however, described significant systemic issues in survivors' access to this mechanism. For example, migrants facing deportation have only 15 days to apply from the point at which a CBSA officer determines that they are eligible to apply for a PRRA. During this time, the individual is not subject to removal but may be detained. Evidence presented at the inquest showed that Lucía intended to apply for a PRRA, however, the process itself proved challenging due to difficulties meeting with legal counsel, language barriers and challenges accessing an interpreter, lack of access to the necessary paperwork which did not travel with detainees, and multiple issues with the phone system that limited the capacity of detainees to access necessary evidence (Gros \& Van Groll, 2015; Ministry of Justice, 2014). One service provider I interviewed described how the process of PRRA was difficult enough for migrant detainees, but that for survivors in particular, the process was fraught with "procedural unfairness" (Interview, Toronto, 2014). As she explained: "This is really hard for anyone who has experienced trauma, but especially for women who are survivors of violence, where it takes so long for people to even be able to speak about their experiences, to remember their experiences, to understand what's relevant, to get evidence, it takes so long" (emphasis in original). In Lucía's case, when the deadline for her PRRA passed, she contacted a CBSA officer in a panic to let him know that she still wanted to apply. Reports showed, however, that the CBSA officer failed to inform Lucía of her right to apply regardless of missing the deadline - instead the officer told her it was too late to apply, and she would be deported (Ministry of Justice, 2014).

In addition to the problematic conditions of detention experienced by all detainees, my interviewees pointed out how practices of confinement can also be triggering for survivors of gender-based violence, who may experience additional psycho-social health impacts from being detained (Goldring \& Landolt, 2013). While we cannot know the specific health impacts of detention on Lucía, who according to the inquest self-reported as being in "crisis," many of the service providers I interviewed described how detention exacerbated the effects of gender-based violence and trauma in migrant women's lives (Ministry of Justice, 2014). Indeed, evidence presented at the inquest described Lucía as "withdrawn and uncommunicative" in her final days. One of her detention hearings needed to be cut short because "she was sobbing uncontrollably" (Ministry of Justice, 2014). As one of my interviewees put it, "detention is the nice immigration word for it, but it's horrific. It's jail. It's not supposed to be punishment, but it is... Pretty much every woman I work with has identified the immigration system as another form of trauma" (Interview, Toronto, 2014). Perhaps it is not surprising then, 
that activists responding to crimmigration in Canada often described deportation and detention as forms of state violence against women - a framing that I observed frequently over my four years in the field (Abji, 2016). Lucía's tragic suicide and death within that system can thus be seen not as an aberration or exception to the rule, but rather as an outcome of that systemic violence.

\section{Discussion and Conclusion}

In this research, I showed how current approaches to crimmigration were useful yet limited in teasing out the convergences between criminalization and immigration that shape the experiences of non-citizens. In my case analysis of Lucía's tragic death in detention, I demonstrated how securitized policies against "immigration fraud" shaped the contexts of reception that Lucía experienced as a refugee claimant from Mexico. The Canadian state's expansion of border enforcement practices in the post-9/11 period not only intensified her experiences of precarity as an undocumented migrant living in Vancouver, but also exposed her to punitive practices mirroring criminal prosecutions, such as her housing in a women's prison.

When I centred Lucía's positionality as a survivor of gender-based violence, however, a deeper story emerged not sufficiently addressed in the crimmigration literature. Applying Crenshaw's notion of structural intersectionality, I demonstrated how, for survivors of gender-based violence like Lucía, immigration is not only a pathway to citizenship, but also a strategy for surviving the multiple sources of violence in their lives. I then argued that the growing nexus between migration, security and gender-based violence effectively punished strategies of survivorship used by oftenracialized migrant women as a key component of crimmigration processes. Drawing from my own fieldwork and interviews with advocates, I showed how the strategies that feminist organizations had developed to help migrant women navigate access to citizenship were routinely shut down through antifraud and anti-crime measures. These were often because of the genderedracialized effects of seemingly gender-neutral and race-neutral policies. In Lucía's case, restrictions on access to refugee claims limited the timeframes that she and others like her had access to in order to gather evidence in a system already rife with misogynistic beliefs and practices. Her detention in a women's prison exposed Lucía to potential re-traumatization as well as new risks of experiencing sexual violence without independent oversight, in addition to the mental health effects of deportation and detention that come with such punitive measures for all detainees. Finally, the lack of independent oversight meant that the series of bureaucratic errors and systemic violations of her rights that Lucía encountered failed to offer her the protection from self-harm that she might have otherwise had. Overall, my re-reading of Lucía's story showed how crimmigration is not only a form of legal violence 
affecting migrant access to justice, but also a way in which survivorship - or migrant women's strategies for surviving gender-based violence - are also being criminalized through these processes.

While my case analysis was illustrative rather than representative, the findings have important implications for crimmigration scholarship moving forward. First, the research calls for greater attention to the complex positionality of racialized women survivors of gender-based violence. This would necessitate better access to data ranging from the demographic composition of migrants in detention to the lived experiences of survivors across multiple categories of difference both prior to and in detention. Indeed, future research should continue to push the intersectional frame further to consider how gender-based violence intersects with other salient dimensions such as sexuality, gender-identity, ableism, ageism and so on (Stasiulis, 1999). Finally, attention to the intersectional dimensions of crimmigration have important implications for how migrant justice is theorized and achieved. By illustrating the ways in which crimmigration punishes survivors and criminalizes survivorship, this research calls for a more robust understanding of the links between migrant justice and freedom from genderbased violence as fundamental to the project of reforming and transforming the crimmigration system.

\section{Acknowledgements}

With respectful gratitude to Lucía Dominga Vega Jiménez: may your story help others. Thank you to the research participants who so graciously shared their insights and knowledge with me. I also gratefully acknowledge comments from the editors and anonymous reviewers, as well as from Daiva Stasiulis, Kristie O’Neill, Paulina García-Del Moral and workshop participants at Carleton University and the University of Toronto who provided generative feedback on this paper. This research was supported by funding from the Social Sciences and Humanities Research Council (SSHRC) as part of a post-doctoral fellowship at the Department of Sociology and Anthropology, Carleton University.

\section{References}

Aberman, T. (2014). Gendered perspectives on refugee determination in Canada. Refuge: Canada's Journal on Refugees, 30(2), 57-66.

Abji, S. (2016). Because deportation is violence against women: On the politics of state responsibility and women's human rights. Social Politics, 23(4), 483-507.

Abji, S. (2018). Postnational acts of citizenship: How an anti-border politics Is shaping feminist spaces of service provision in Toronto, Canada. International Feminist Journal of Politics, 20(4), 501-523. 
Abji, S., Korteweg, A. C., \& Williams, L. H. (2019). Culture talk and the politics of the new right: Navigating gendered racism in attempts to address violence against women in immigrant communities. Signs: Journal of Women in Culture and Society, 44(3), 797-822.

Amnesty International. (2015). Canada: Submission to the UN Human Rights Committee. AMR 20/1806/2015.

Arbel, E., \& Brenner, A. (2013). Bordering on failure: Canada-US border policy and the politics of refugee exclusion. Cambridge, MA: Harvard Immigration and Refugee Law Clinical Program, Harvard Law School. Retrieved from https://harvardimmigrationclinic.files.wordpress.com/2013/11/bordering-on-failureharvard-immigration-and-refugee-law-clinical-program1.pdf

Armenta, A. (2017). Racializing crimmigration: Structural racism, colorblindness, and the institutional production of immigrant criminality. Sociology of Race \& Ethnicity, 3(1), 8295.

Atak, I., Hudson, G., \& Nakache, D. (2018). The securitisation of Canada's refugee system: Reviewing the unintended consequences of the 2012 reform. Refugee Survey Quarterly, 37(1), 1-24.

Ball, D. P. (2014, July 10). Transit police report riders to Immigration nearly every day. The Tyee. Retrieved from https://thetyee.ca/News/2014/07/10/Transit-Police-ImmigrationStatus/

Béchard, J., \& Elgersma, S. (2012). Legislative summary of Bill C-31: An Act to amend the Immigration and Refugee Protection Act, the Balanced Refugee Reform Act, the Marine Transportation Security Act and the Department of Citizenship and Immigration Act. Retrieved from https://lop.parl.ca/staticfiles/PublicWebsite/Home/ResearchPublications/LegislativeSumma ries/PDF/41-1/c31-e.pdf

Bergen, H., \& Abji, S. (2020). Facilitating the carceral pipeline: Social work's role in funneling newcomer children from the child protection system to jail and deportation. Affilia: Journal of Women \& Social Work, 35(1), 34-48.

Bhuyan, R., Osborne, B., Zahraei, S., \& Tarshis, S. (2014). Unprotected and unrecognized: Canadian immigration policy and violence against women 2008-2013. Toronto, ON: Migrant Mothers Project, University of Toronto. Retrieved from http://www.migrantmothersproject.com/report/

Bosworth, M., Fili, A., \& Pickering, S. (2016). Women's immigration detention in Greece: Gender, control and capacity. In M. J. Guia, R. Koulish \& V. Mitsilegas (Eds.), Immigration detention, risk and human rights (pp. 157-170). Berlin, DE: Springer.

Bosworth, M., \& Turnbull, S. (2014). Immigration detention, punishment, and the criminalization of migration. In S. Pickering \& J. Hamm (Eds.), The Routledge Handbook on Crime and International Migration (pp. 121-136). London: Routledge.

Bourbeau, P. (2018). Detention and immigration: Practices, crimmigration, and norms. Migration Studies, 7(1), 83-99.

Brané, M., \& Wang, L. (2013). Women: The invisible detainees. Forced Migration Review, 44, 37-39.

Burgmann, T. (2014, October 1). Lucia Vega Jimenez: Timeline of a tragedy. Vancouver Sun. Retrieved from http://www.vancouversun.com/health/Lucia+Vega+Jimenez+Timeline+tragedy/10253737/ story.html

Canadian Press. (2018, July 17). Vancouver police draft guidelines for interacting with undocumented populations. Vancouver Sun. Retrieved from https://vancouversun.com/news/local-news/vancouver-police-draft-guidelines-forinteracting-with-undocumented-migrants

Carastathis, A., Kouri-Towe, N., Mahrouse, G., \& Whitley, L. (2018). Intersectional feminist interventions in the 'Refugee Crisis': Introduction. Refuge: Canada's Journal on Refugees, 34(1), 3-15.

CBSA (Canadian Border Services Agency), n.d. Removals processed by region by year. Government of Canada. Retrieved from https://open.canada.ca/data/en/dataset/87ccfc741065-4399-aeb7-34a07de25c0b 
Cervantes, A. G., Menjívar, C., \& Staples, W. G. (2017). 'Humane' immigration enforcement and Latina immigrants in the detention complex. Feminist Criminology, 12(3), 269-292.

Collier, M., \& Daniel, M. (2019). The production of trans illegality: Cisnormativity in the US immigration system. Sociology Compass, 13(4), e1266.

Combahee River Collective. (1983). Combahee River Collective Statement: Black feminist organizations in the 70s and 80s. New York: Kitchen Table/Women of Color Press.

Crenshaw, K. (1991). Mapping the margins: Intersectionality, identity politics, and violence against women of color. Stanford Law Review, 43(6), 1241-1299.

Dawson, C. (2016). In plain sight: Documenting immigration detention in Canada. Migration, Mobility \& Displacement, 2(2), 126-140.

Dyck, D. (2015, June 15). Lift veil of secrecy on detainee deaths in Border Services custody: Editorial. The Toronto Star. Retrieved from http://www.thestar.com/opinion/editorials/2015/06/15/lift-veil-of-secrecy-on-detaineedeaths-in-border-services-custody-editorial.html

EIDN (End Immigration Detention Network). (2014, June). Indefinite, arbitrary and unfair: The truth about immigration detention in Canada. Retrieved from https://endimmigrationdetention.com/resources/

García-Del Moral, P. (2016). Transforming feminicidio: Framing, institutionalization and social change. Current Sociology, 64(7), 1017-1035.

Garner, S. (2015). Crimmigration: When criminology (nearly) met the sociology of race and ethnicity. Sociology of Race \& Ethnicity, 1(1), 198-203.

GDP (Global Detention Project). (2012). Canada detention profile. Retrieved from https://www.globaldetentionproject.org/countries/americas/canada

GDP (Global Detention Project). (2018, June). Immigration detention in Canada: Important reforms, ongoing concerns. Retrieved from https://www.globaldetentionproject.org/immigration-detention-in-canada-importantreforms-ongoing-concerns

Glenn, E. N. (2015). Settler colonialism as structure: A framework for comparative studies of US race and gender formation. Sociology of Race \& Ethnicity, 1(1), 52-72.

Golash-Boza, T. (2016). The parallels between mass incarceration and mass deportation: An intersectional analysis of state repression. Journal of World-Systems Research, 22(2), 484509.

Golash-Boza, T., \& Hondagneu-Sotelo, P. (2013). Latino immigrant men and the deportation crisis: A gendered racial removal program. Latino Studies, 11(3), 271-292.

Goldring, L., Berinstein, C., \& Bernhard, J.K. (2009). Institutionalizing precarious migratory status in Canada. Citizenship Studies, 13(3), 239-265.

Goldring L., \& Landolt, P. (Eds.) (2013). Producing and negotiating non-citizenship: Precarious legal status in Canada. Toronto, ON: University of Toronto Press.

Gros, H. (2016). Invisible citizens: Canadian children in immigration detention. International Human Rights Program (IHRP),University of Toronto Faculty of Law. Retrieved from https://ihrp.law.utoronto.ca/sites/ihrp.law.utoronto.ca/files/PUBLICATIONS/ReportInvisibleCitizens.pdf

Gros, H., \& Van Groll, P. (2015). 'We have no rights': Arbitrary imprisonment and cruel treatment of migrants with mental health issues in Canada. International Human Rights Program (IHRP), University of Toronto Faculty of Law. Retrieved from http://ihrp.law.utoronto.ca/utfl_file/count/PUBLICATIONS/IHRP\%20We\%20Have\%20No \%20Rights\%20Report\%20web\%20170615.pdf

Hernández, C. C. G. (2017). Abolishing immigration prisons. Boston University Law Review, 97(1), 245-300.

JRIC (Justice for Refugees and Immigrants Coalition). (2012, March). Protect Refugees from Bill C-31: A joint statement. Canadian Council for Refugees. Retrieved from https://ccrweb.ca/en/protect-refugees-c31-statement

Lee, E. O. J. (2019). Responses to structural violence: The everyday ways in qhich queer and trans migrants with precarious status respond to and resist the Canadian immigration regime. International Journal of Child, Youth \& Family Studies, 10(1), 70-94. 
Lorde, A. (1984). Sister outsider: Essays and speeches. New York: Crossing Press.

Mattoo, D., Mann, R., \& Romano, J. (2017). Race, gendered violence, and the rights of women with precarious immigration status. Community Leadership in Justice Fellowship of Law Foundation of Ontario, Factor-Inwentash Faculty of Social Work, University of Toronto. Retrieved from http://hdl.handle.net/1807/93696

Maynard, R. (2017). Policing Black lives: State violence in Canada from slavery to the present. Black Point, NS: Fernwood.

McKinnon, S. L. (2016). Gendered asylum: Race and violence in US law and politics. Indianapolis, IL: University of Illinois Press.

Menjívar, C., Cervantes, A. G., Alvord, D. (2018). The expansion of 'crimmigration', mass detention, and deportation. Sociology Compass, 12(4), e12573

Ministry of Justice, British Columbia, Canada. (2014). Verdict at Coroner's Inquest. BC Ministry of Justice File No: 2013:0380:0004.

Moffette, D. (2018). The jurisdictional games of immigration policing: Barcelona's fight against unauthorized street vending. Theoretical Criminology. Retrieved from https://journals.sagepub.com/doi/pdf/10.1177/1362480618811693

Molnar, P., \& Silverman, S. J. (2017, November 14). Migrants are dying in detention centres: When will Canada act? The Conversation. Retrieved from https://theconversation.com/migrants-are-dying-in-detention-centres-when-will-canada-act87237

Molnar, P., \& Silverman, S. J. (2018, April 15). How Canada's immigration detention system spurs violence against women. The Conversation. Retrieved from https://theconversation.com/how-canadas-immigration-detention-system-spurs-violenceagainst-women-95009

NIJC (National Immigrant Justice Center). (2014, May). Eliminating the detention bed quota helps women. Retrieved from www.immigrantjustice.org

Nobe-Ghelani, C. (2017). Inner border making in Canada: Tracing gendered and raced processes of immigration policy changes between 2006 and 2015. Canadian Review of Social Policy/Revue Canadienne de Politique Sociale, 77, 44-66.

Paterson, J. (2014, October 20). Distressed, afraid and alone: Tragic story slowly unfolds at Lucía Vega Jiménez Inquest. B.C. Civil Liberties Association. Retrieved from https://bccla.org/2014/10/distressed-afraid-and-alone-tragic-story-slowly-unfolds-at-luciavega-jimenez-inquest/

Pratt, A. (2005). Securing borders: detention and deportation in Canada. Vancouber, BC: UBC Press.

Rabin, N. (2009). Unseen prisoners: A report on women in immigration detention facilities in Arizona. Georgetown Immigration Law Review, 23, 695.

Razack, S. (Ed.). (2002). Race, space, and the law: Unmapping a white settler society. Toronto, ON: Between the Lines.

Razack, S. (2017). Human waste and the border: A vignette. Law, Culture \& the Humanities. Retrieved from https://journals.sagepub.com/doi/pdf/10.1177/1743872117749524

Romero, M. (2008). Crossing the immigration and race border: A critical race theory approach to immigration studies. Contemporary Justice Review, 11(1), 23-37.

Shantz J. (2014, March 14). Border security and the neoliberal 'dungeon': A Canadian case. Border Criminologies [Blog], Retrieved from http://bordercriminologies.law.ox.ac.uk/border-security-and-neoliberal/

Silverman, S. J. (2014). In the wake of irregular arrivals: Changes to the Canadian immigration detention system. Refuge, 30(2), 27-34.

Silverman, S. J., \& Molnar, P. (2016). Everyday injustices: Barriers to access to justice for immigration detainees in Canada. Refugee Survey Quarterly, 35(1), 109-127.

Singh, R. (2016). Importing feminisms: Racialized migrants and antiviolence activism. Social Politics, 23(4), 508-30.

Stasiulis, D. (1999). Feminist intersectional theorizing. In P. Li (Ed.), Race and ethnic relations in Canada (pp. 347-397). Toronto, ON: Oxford University Press.

Stasiulis, D. and Bakan, A. B. (2005). Negotiating Citizenship: migrant women in Canada and the global system. Toronto: University of Toronto Press. 
Stasiulis, D., \& Jhappan, R. (1995). The fractious politics of a settler society: Canada. In D. Stasiulis \& N. Yuval-Davis (Eds.), Unsettling settler societies: Articulations of gender, race, ethnicity and class (pp. 95-131). Thousand Oaks, CA: Sage.

Stumpf, J. P. (2006). The crimmigration crisis: Immigrants, crime, and sovereign power. American University Law Review, 56, 367.

Swain, D., Wesley, A., \& Davis, S. (2019. Feb 4). Harassment, sexual assault among alleged misconduct by border agents investigated by CBSA. CBC News. Retrieved from https://www.cbc.ca/news/canada/cbsa-files-abuse-atip-1.4999473.

Track, L., \& Paterson, J. (2017). Oversight at the border: A model for independent accountability at the Canada Border Services Agency. British Columbia Civil Liberties Association $(B C C L A)$. Retrieved from www.bccla.org

TND (Transportation Not Deportation Campaign). (2015). Public transit should not be a border checkpoint: key facts. Retrieved from https://transportationnotdeportation.wordpress.com/key-facts/

Tunney, C. (2019. March 20). Budget includes watchdog agency for border officers. CBC News. Retrieved from https://www.cbc.ca/news/politics/cbsa-independent-watchdog-1.5063543

United Nations Committee on Human Rights. (2015). International covenant on civil and political rights. $\mathrm{CCPR} / \mathrm{C} / \mathrm{CAN} / \mathrm{CO} / 6$. Retrieved from http://tbinternet.ohchr.org/_layouts/treatybodyexternal/SessionDetails1.aspx?SessionID=89 9\&Lang=en\#sthash.XzzyC1Bz.dpuf

UNHCR (United Nations High Commissioner for Refugees). (2012). Detention guidelines: Guidelines on the applicable criteria and standards relating to the detention of asylumseekers and alternatives to detention. Retrieved from http://www.unhcr.org/refworld/docid/503489533b8.html

Villegas, P. (2015). Fishing for precarious status migrants: Surveillant assemblages of migrant illegalization in Toronto, Canada. Journal of Law \& Society, 42(2), 230-252.

Walia, H. (2013). Undoing border imperialism. Chico, CA: AK Press.

Walia, H., \& Hassan, S. (2014, October 2). Electronic monitoring not an alternative to immigration detention. Province Opinion. Retrieved from https://theprovince.com/opinion/harsha-walia-and-syed-hussan-electronic-monitoring-notan-alternative-to-immigration-detention

Weber, L. (2002). The detention of asylum seekers: 20 reasons why criminologists should care. Current Issues in Criminal Justice, 14(1), 9-30.

Women for Refugee Women. (2015). I am human: Refugee women's experiences of detention in the UK. Retrieved from http://www.thebromleytrust.org.uk/files/wrw_iamhuman.pdf

Woo, A. (2014, January 31). Woman who died in CBSA custody feared returning to domestic trouble in Mexico. Globe \& Mail. Retrieved from https://www.theglobeandmail.com/news/british-columbia/woman-who-died-in-cbsacustody-feared-returning-to-domestic-trouble-in-mexico/article16644691/ 